\title{
Gaseous emissions during concurrent combustion of biomass and non-recyclable municipal solid waste
}

\author{
René Laryea-Goldsmith, John Oakey, Nigel J Simms*
}

\begin{abstract}
Background: Biomass and municipal solid waste offer sustainable sources of energy; for example to meet heat and electricity demand in the form of combined cooling, heat and power. Combustion of biomass has a lesser impact than solid fossil fuels (e.g. coal) upon gas pollutant emissions, whilst energy recovery from municipal solid waste is a beneficial component of an integrated, sustainable waste management programme. Concurrent combustion of these fuels using a fluidised bed combustor may be a successful method of overcoming some of the disadvantages of biomass (high fuel supply and distribution costs, combustion characteristics) and characteristics of municipal solid waste (heterogeneous content, conflict with materials recycling). It should be considered that combustion of municipal solid waste may be a financially attractive disposal route if a 'gate fee' value exists for accepting waste for combustion, which will reduce the net cost of utilising relatively more expensive biomass fuels.

Results: Emissions of nitrogen monoxide and sulphur dioxide for combustion of biomass are suppressed after substitution of biomass for municipal solid waste materials as the input fuel mixture. Interactions between these and other pollutants such as hydrogen chloride, nitrous oxide and carbon monoxide indicate complex, competing reactions occur between intermediates of these compounds to determine final resultant emissions.

Conclusions: Fluidised bed concurrent combustion is an appropriate technique to exploit biomass and municipal solid waste resources, without the use of fossil fuels. The addition of municipal solid waste to biomass combustion has the effect of reducing emissions of some gaseous pollutants.
\end{abstract}

\section{Background}

Concurrent combustion of biomass and municipal solid waste (MSW) offers a method of electricity and heat generation using renewable energy resources. At small scale, biomass is recognised as a form of renewable energy that is capable of meeting both heat and electricity demand most effectively in the form of combined heat and power, contributing towards international commitments to minimise environmental damage [1]. Further efficiency in using biomass can be obtained where thermal conversion occurs adjacent to areas of demand (such as cities) for cooling, i.e. 'tri-generation', or combined cooling, heating and electrical power. Therefore, small-scale biomass combustion offers an

\footnotetext{
* Correspondence: n.j.simms@cranfield.ac.uk

Energy Technology Centre, Cranfield University, Cranfield, Bedfordshire, UK
}

excellent method to exploit heat energy. In contrast, wind turbines and large-scale pulverised fuel power stations are primarily used to produce electricity only, where the pulverised fuel may contain biomass for cofiring. Within waste management government policy, energy recovery from MSW is seen as an essential requirement for diverting waste from landfill disposal. As a result of Europe-wide legislation and government targets to minimise the environmental impact of landfill disposal, for example it is forecast that energy recovery within UK is expected to comprise $25 \%$ of MSW disposal by 2020; recent rates are $10 \%$ [2]. Combustion of biomass is often assumed to provide nil net anthropogenic carbon dioxide emissions and carbon emissions associated with biomass collection and distribution activities are similar to those for fossil fuels [3] and therefore may be accepted as being of minimal damage 
to the environment. In contrast, the combustion of MSW is often considered to be detrimental both to human health and environmental management primarily because of various gaseous pollutants, most commonly public health risk concern about poly-chlorinated dibenzo-p-dioxins and dibenzofurans [4]. The most common assessment of biomass and MSW fuels has been to investigate combustion of biomass with coal, or coal with MSW. This paper is an investigation into the combustion of biomass and source separated MSW, specifically the extent of gaseous emissions.

Dried distillers' grains with solubles (DDGS) is investigated in this paper as an example biomass fuel, produced as an agricultural by-product in the manufacture of ethanol by fermentation. Historically, DDGS is used as animal feed but as a result of increased ethanol production, it is forecast to be of greater use as an energy source [5]. The MSW fuel was selected from the source-separated rejected material of a materials recycling facility. At least within the UK, combustion of MSW is considered by some to be a barrier against efforts to increase historically low levels of materials recycling. As a consequence, this material fraction was identified as a fuel source that could be exploited without impact upon the higher priority recycling of waste materials and therefore maintaining the "waste hierarchy" of sequentially preferred methods of waste management: $a$ ) reduction of waste $b$ ) reuse of waste materials $c$ ) recycling \& composting $d$ ) energy recovery $e$ ) landfill with energy recovery $f$ ) landfill [2]. This material is termed in this paper: "materials recycling facility residue" (MRFR), to represent a truly residual waste fuel that does not conflict with materials recycling activities.

A pilot-scale fluidised bed combustor was used to burn biomass and MRFR in mixtures of various proportions. The effect of the MRFR waste fraction of the fuel mixture upon gaseous pollutant emissions during combustion was investigated using an FTIR flue gas analyser. This analytical technique suggested that addition of the MRFR to the fuel mixture inhibited emission of some pollutants. Use of rejected material from materials recycling facilities suggests that energy conversion of such waste is practicable and that variation in the composition of the fuel types can be tolerated, to represent the geographical constraints and seasonal changes in availability of these fuels.

\section{Results}

The general target control parameters for operation of the combustor were as follows: a) temperature $850^{\circ} \mathrm{C}$ (to mimic the mandatory minimum temperature required for a combustor consuming MSW as a fuel); b) flue gas oxygen content $<10 \%$ (to indicate operational efficiency); c) duration at least two hours. The fluidised bed material consisted of silica sand and industrial limestone, $50 \%$ by weight of each material and total bulk mass $22 \mathrm{~kg}$ and the level of fluidisation was measured by use of a micromanometer (model MDG FC001, Furness Controls; Burgess UK), to monitor the differential pressure caused by the dynamic motion of gas through the fluidised bed particles. Operating conditions for the fluidised bed combustor are summarised in Table 1.

\section{Gas pollutant emissions}

This paper is focussed on emissions of hydrogen chloride, nitrogen oxides and sulphur oxides from DDGSMRFR combustion in the fluidised bed combustor. The following graphs (Figures 1, 2, 3, 4, 5, 6, 7, 8, 9 and 10) summarise these emissions for the range of fuel mixtures studied. Emissions data presented here correspond to periods during the combustion test when stable combustion conditions were maintained. The fuel mixtures of DDGS and MRFR consisted of the following DDGS fractions, by weight: $90 \%$; $80 \% ; 50 \%$; $30 \%$. Where graphs show temperature, this is a measure of the 'in-bed' temperature of fluidised bed material within the fluidised bed combustor. The 'box and whisker' graphs (Figures 1 and 2) are interpreted as follows: median value represented by the bold horizontal line; interquartile range (contains $50 \%$ of data set) represented by the area inside the box; horizontal lines above and below interquartile range box represent maximum and minimum values in data set; 'outliers' represented by circle $(\circ)$ symbol and defined as a datum 1.5 greater and/or lesser than the interquartile range.

\section{Discussion}

Combustion of waste materials requires attention to ensure complete combustion is achieved in order to minimise gaseous pollutant emissions. The variation in temperature experienced during combustion of biomass and MRFR fuels may be attributed to volatile components in both fuel fractions being released in a random manner as the fuel mixes with the fluidised bed during combustion. The fuel was observed to ignite and burn often almost immediately upon entry into the freeboard area, as has been reported elsewhere during co-combustion with coal and paper, plastic waste [6]. Temperature per se has a significant impact upon reaction rates in general and in the case of combustion, gaseous emissions may either be enhanced or inhibited by increases in the combustion temperature. For example, carbon monoxide is an intermediate species and during combustion in the fluidised bed combustor is likely to be formed within localised regions of the fluidised bed material, where fuel-rich conditions may momentarily occur to prevent complete combustion to carbon dioxide because of insufficient oxygen being present in the 
Table 1 Summary of operation of fluidised bed combustor

\begin{tabular}{|c|c|c|c|c|c|c|}
\hline Fuel mixture & $\begin{array}{c}\text { Fuel feed } \\
\left(\mathrm{kg} \mathrm{h}^{-1}\right)\end{array}$ & $\begin{array}{l}\text { Inlet air } \\
\left(1 \mathrm{~min}^{-1}\right)\end{array}$ & $\begin{array}{l}\text { Combustion temperature } \\
\text { (fluidised bed sand, }{ }^{\circ} \mathrm{C} \text { ) }\end{array}$ & $\begin{array}{c}\text { Flue gas content } \mathrm{CO}_{2} \\
\text { (\% vol.) }\end{array}$ & $\begin{array}{l}\text { Flue gas content } \mathrm{O}_{2} \\
\text { (\% vol.) }\end{array}$ & $\begin{array}{l}\text { Flue gas content } \mathrm{H}_{2} \mathrm{O} \\
\text { (\% vol.) }\end{array}$ \\
\hline DDGS & 6 & 1400 & 855 (848) & $8.5(8.6)$ & $11.2(11.1)$ & $9.0(9.2)$ \\
\hline $\begin{array}{l}\text { DDGS-MRFR } \\
(90: 10)\end{array}$ & 5 & 1400 & $888(861)$ & $8.3(7.9)$ & $11.6(12.0)$ & $8.5(8.3)$ \\
\hline $\begin{array}{l}\text { DDGS-MRFR } \\
(80: 20)\end{array}$ & 5 & 1400 & $864(857)$ & $8.8(8.9)$ & 11.5 (11.4) & $9.4(9.5)$ \\
\hline $\begin{array}{l}\text { DDGS-MRFR } \\
(50: 50)\end{array}$ & 4 & 1400 & 791 (804) & $6.9(7.3)$ & $13.0(12.6)$ & $7.0(7.2)$ \\
\hline $\begin{array}{l}\text { DDGS-MRFR } \\
(30: 70)\end{array}$ & 7 & 1400 & 818 (811) & $10.2(9.5)$ & $9.7(10.2)$ & $9.4(8.8)$ \\
\hline
\end{tabular}

Median values shown for temperature and flue gas data during periods of stable combustion. Corresponding values for entire duration of combustion of fuel mixtures are shown in parentheses. Duration of combustion tests were approximately three hours, except for DDGS 100\% (two hours) and DDGS-MRFR 90:10 (four hours).

local region. The rate of carbon monoxide oxidation is determined significantly by temperature; high combustion temperatures favour complete oxidation. In addition, the availability of free radicals is also a factor for carbon monoxide oxidation [7] and is a complex factor, affected by the presence of other pollutants such that competition for a limited concentration of free radicals will be determined by reaction kinetics.

To demonstrate the effect of free radicals, carbon monoxide emissions have been shown to be potentially higher in the presence of hydrogen chloride [8], an effect attributed to catalytic re-combination of free radicals that reduces the availability of free radical intermediates for consequent carbon monoxide oxidation. This observation is in itself affected by the combustion temperature; higher temperatures (which per se discourage carbon monoxide) reduces the impact of hydrogen chloride as a catalyst to prevent oxidation of carbon monoxide. This study has shown a less clear relationship between temperature, hydrogen chloride content and carbon monoxide emissions. Figure 5 shows that carbon monoxide emission was highest during combustion conditions of high temperature and highest hydrogen chloride content. However, during combustion of both pure DDGS (Figure 3) and DDGS-MRFR (50:50, Figure 4) a random pattern of emissions was found; highest carbon monoxide emissions occurred throughout various temperatures. Carbon monoxide emission was significantly higher for combustion of 30\% DDGS fuel mixture and it is suggested that this is due to the high level of MRFR not having sufficient residence time within the combustion zone to achieve complete combustion of the fuel. These observations would be consistent with previous studies showing how at lower temperatures, the effect of hydrogen chloride is more significant in raising the carbon monoxide level [9].
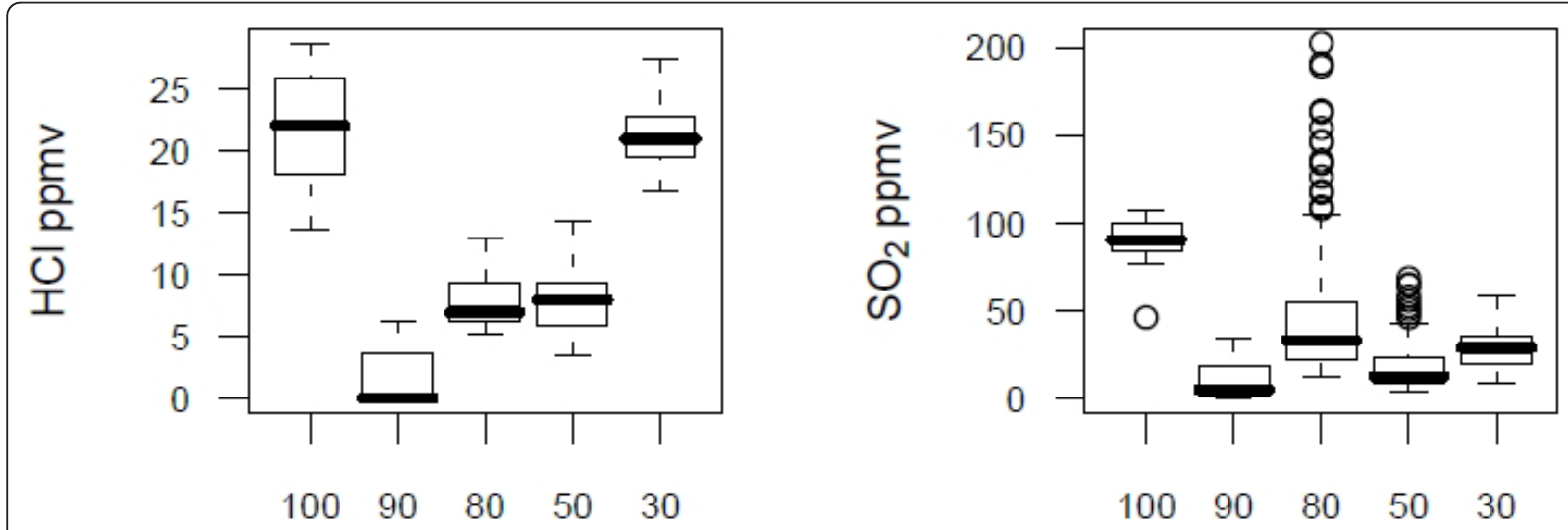

fuel mixture DDGS content (\%)

fuel mixture DDGS content (\%)

Figure 1 Summary of emissions of $\mathrm{HCl}$ and $\mathrm{SO}_{2}$ for the fuel mixtures tested 


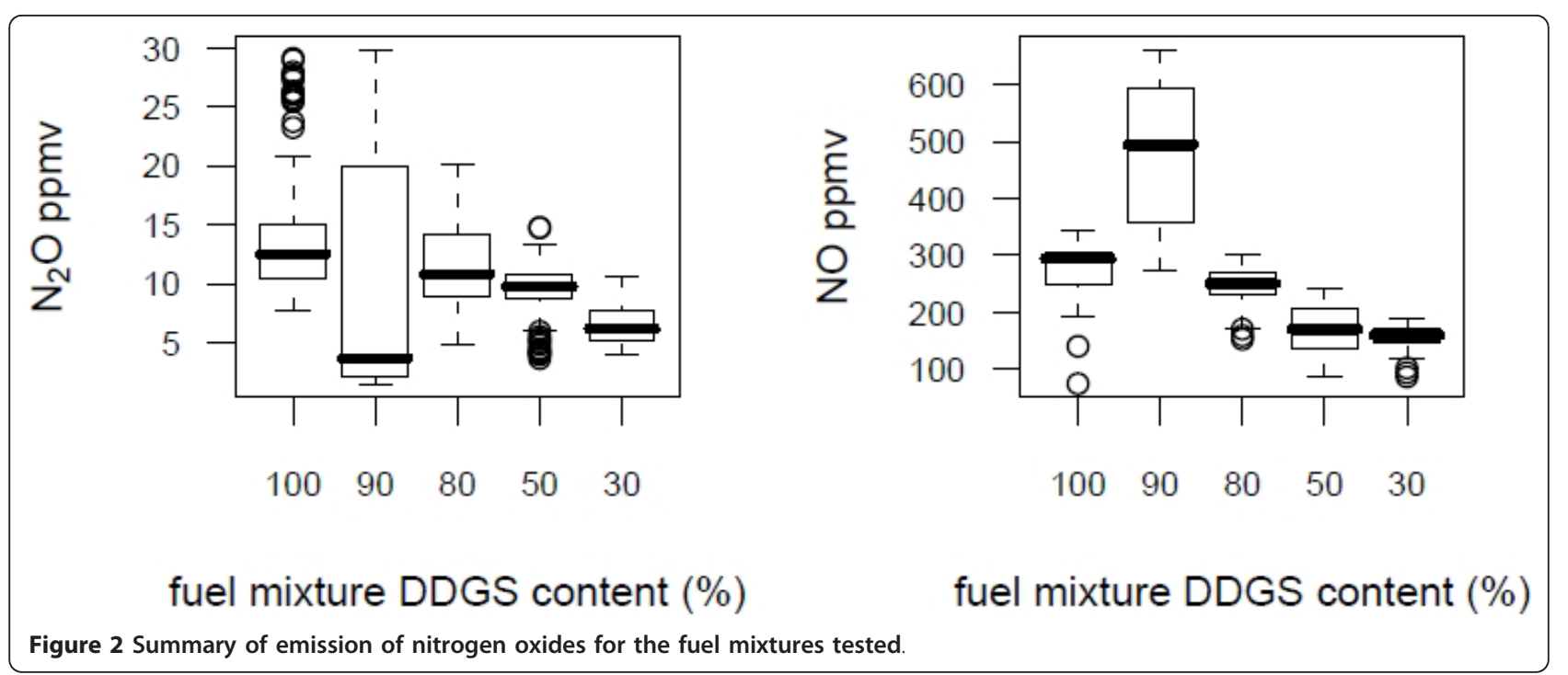

Therefore, the result shows carbon monoxide emissions to be dependent not only on temperature, but is also affected by the chlorine content of the fuel. Although not measured, it is expected that other group 17 halides are also capable of similar effect if present in the fuel, as it has been reported similarly elsewhere that bromide and iodide cations are more effective inhibitors of carbon monoxide oxidation [10].

The sensitivity of carbon monoxide emission to the availability of free radicals has a consequence with respect to emissions of nitrogen and sulphur oxides. formation of these pollutants are themselves also determined by availability of free radicals [11] and it is claimed in general that sulphur reduction of free radicals such as of oxygen atoms reduces the reaction rates of thermal $\mathrm{NO}_{x}$ formation. Therefore it is to be expected that competition for free radicals in order to achieve complete oxidation will be shown as related interactions between concentrations of oxides of carbon, nitrogen and sulphur. During combustion of 30\% DDGS 70\% MRFR, emissions of carbon monoxide occurred when nitric oxide and sulphur dioxide were at their highest (Figure 8). Use of additives in the fluidised bed has a direct impact on sulphur dioxide emissions and

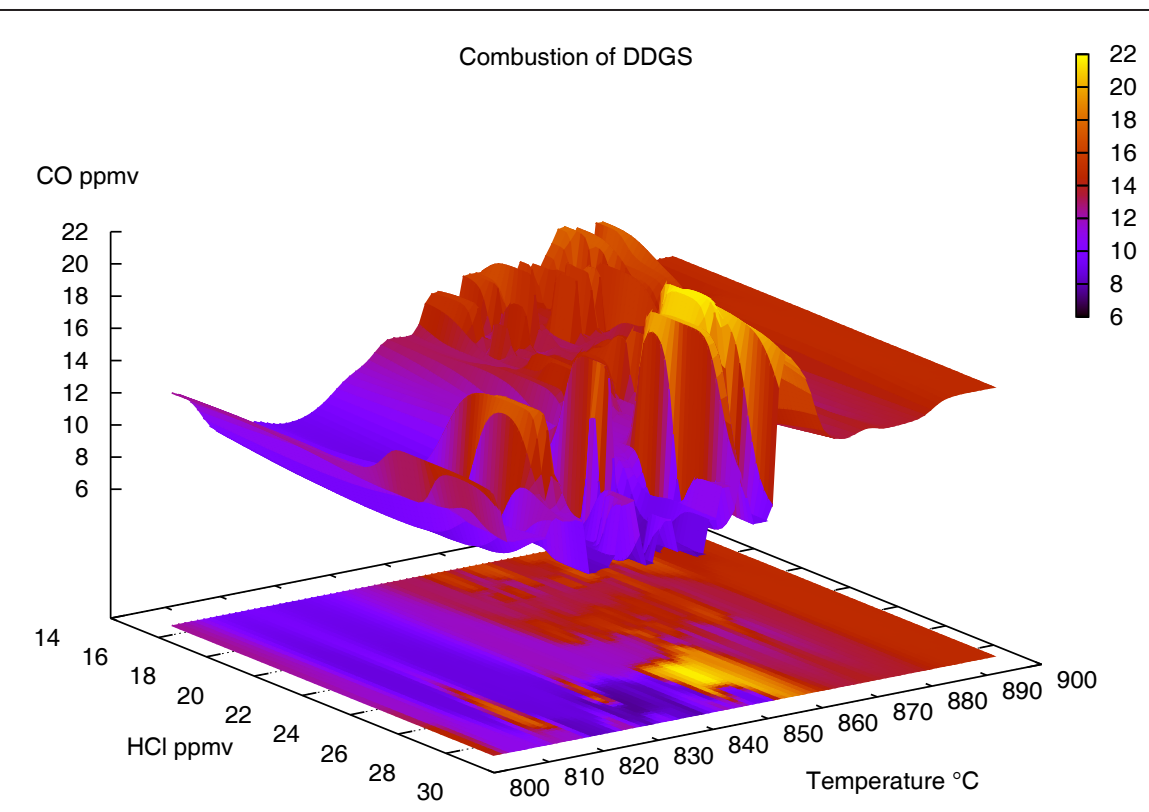

Figure 3 Relationship between simultaneous emissions of $\mathrm{HCl}$ and $\mathrm{CO}$ for a range of combustion temperatures; combustion of DDGS $100 \%$. 


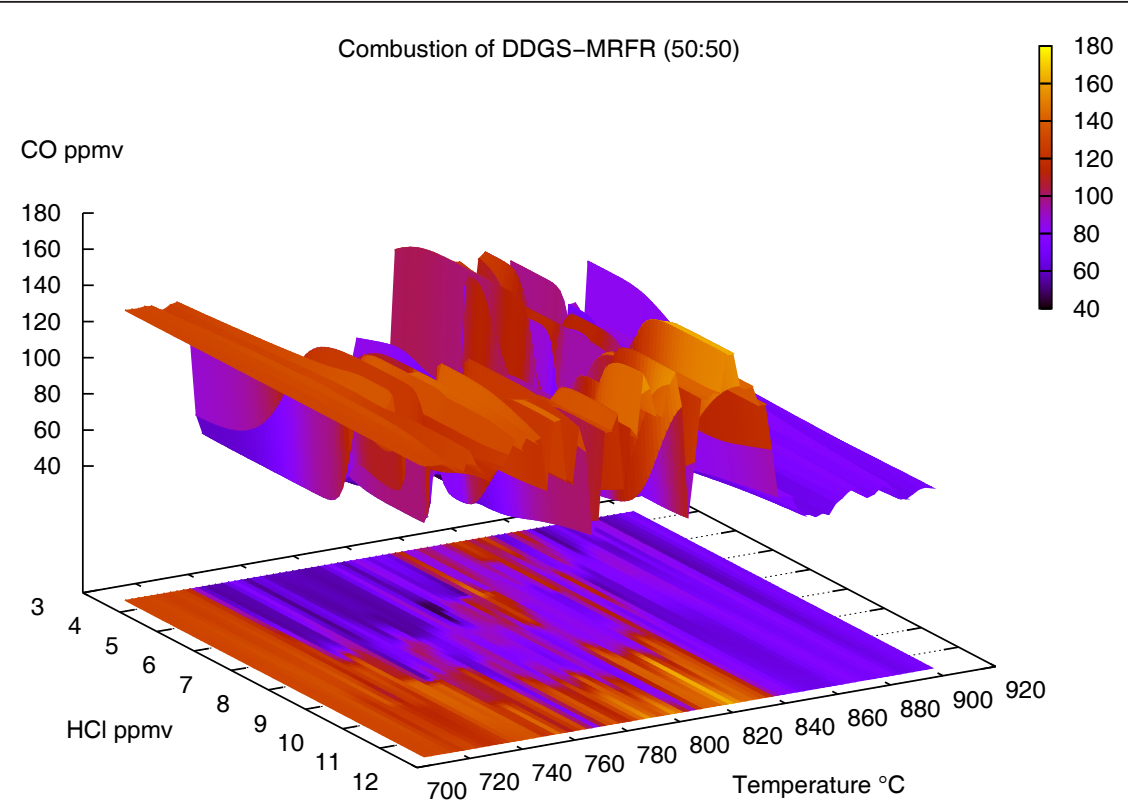

Figure 4 Relationship between simultaneous emissions of $\mathrm{HCl}$ and $\mathrm{CO}$ for a range of combustion temperatures; combustion of DDGSMRFR 50:50.

also indirect effects on other pollutants. Limestone was used in this study to inhibit agglomeration of the fluidised bed material with the fuel ash. Limestone reacts

$$
\mathrm{SO}_{2}+\frac{1}{2} \mathrm{O}_{2} \rightarrow \mathrm{SO}_{3}
$$
with sulphur in the fuel to prevent sulphur dioxide emission in the following series of reactions:

$$
\mathrm{CaCO}_{3} \rightarrow \mathrm{CaO}+\mathrm{CO}_{2}
$$

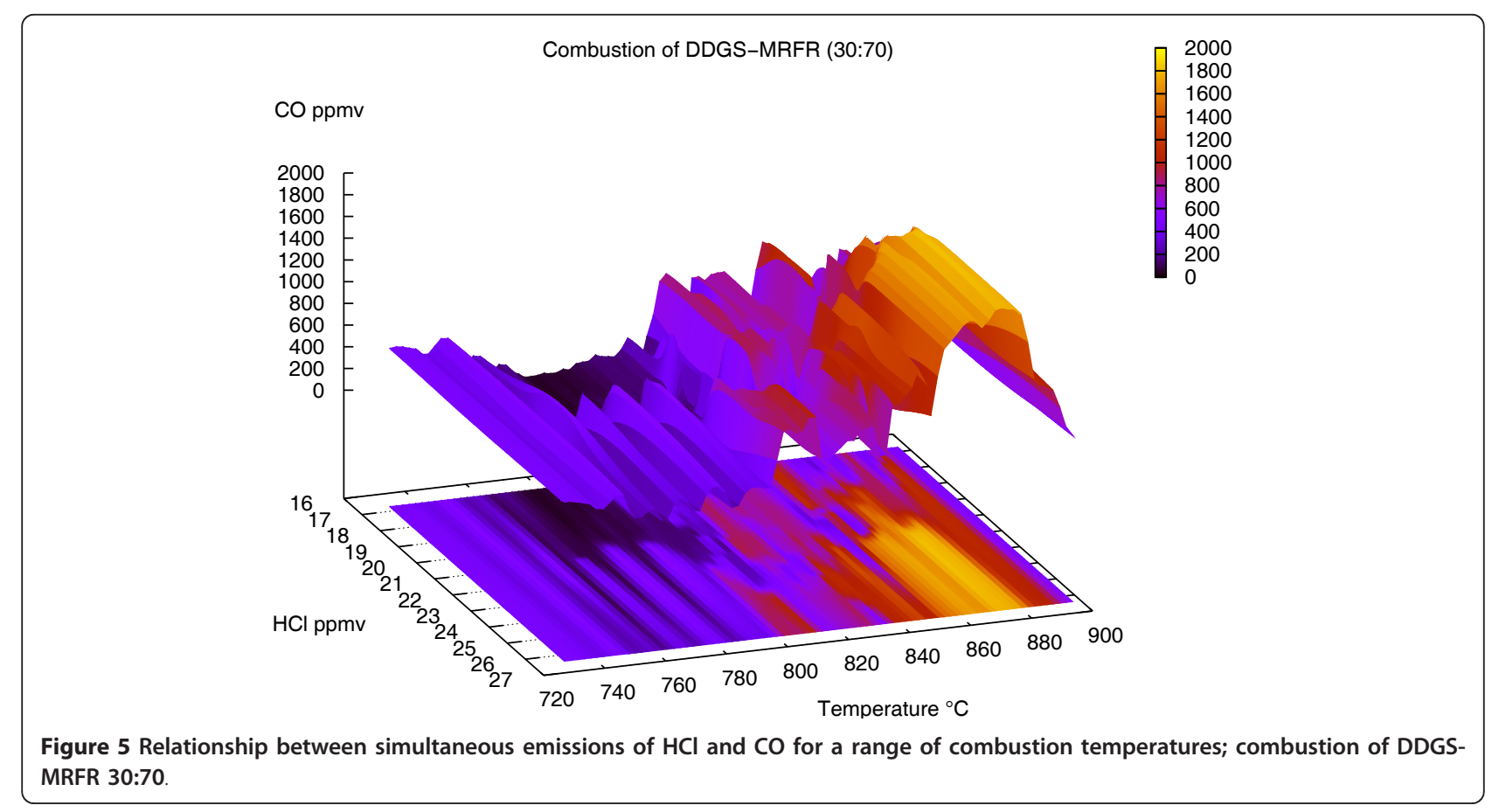




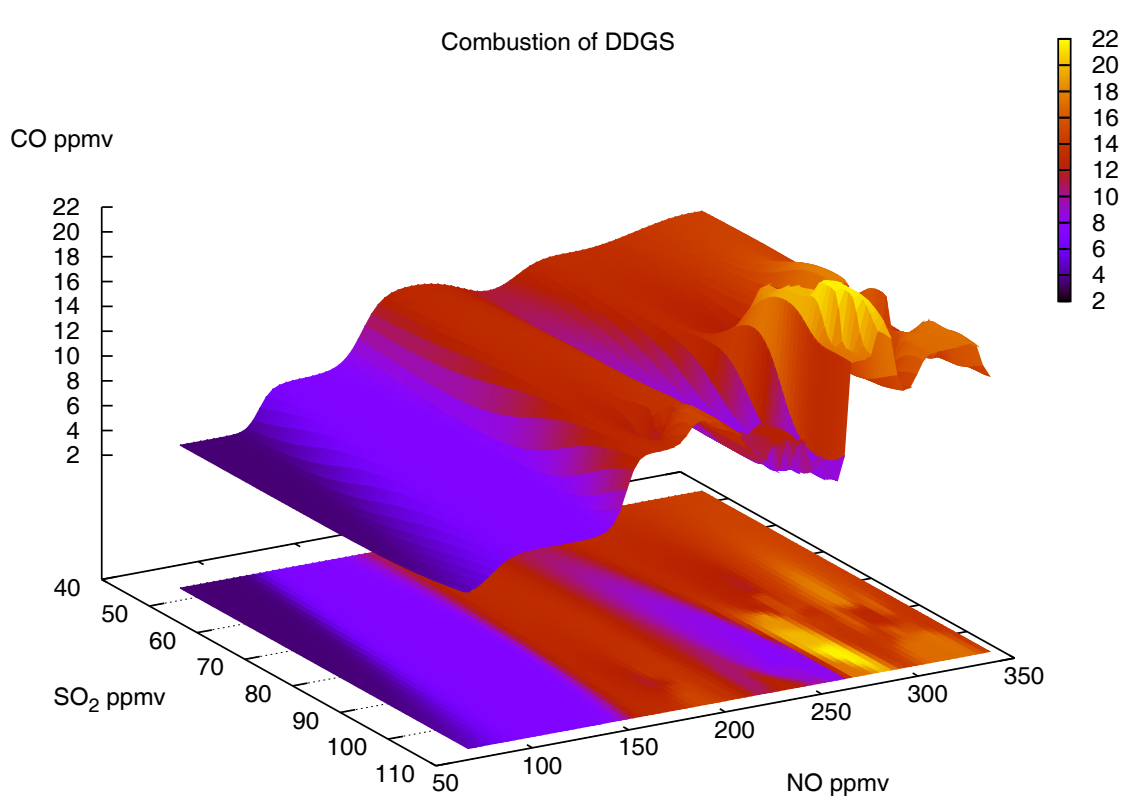

Figure 6 Relationship between simultaneous emissions of $\mathrm{SO}_{2}$, NO and $\mathrm{CO}$; combustion of DDGS $100 \%$.

$$
\begin{aligned}
& \mathrm{CaO}+\mathrm{SO}_{3} \rightarrow \mathrm{CaSO}_{4} \\
& \mathrm{CaO}+\mathrm{SO}_{2}+\frac{1}{2} \mathrm{O}_{2} \rightarrow \mathrm{CaSO}_{4} \\
& \mathrm{CaCO}_{3}+\mathrm{SO}_{2}+\frac{1}{2} \mathrm{O}_{2} \rightarrow \mathrm{CaSO}_{4}+\mathrm{CO}_{2}
\end{aligned}
$$

The absorption of sulphur dioxide is represented by the overall limestone sulphation reaction (equation 5), which is too slow to occur significantly within typical fluidised bed combustor conditions. Instead, sulphur dioxide absorption occurs more favourably via calcination of limestone (i.e. equation 2 followed by equation 4 ), whilst reaction with sulphur trioxide (equation 3 ) is catalysed by the presence of heavy metal salts most likely to originate from the MRFR fuel mixture

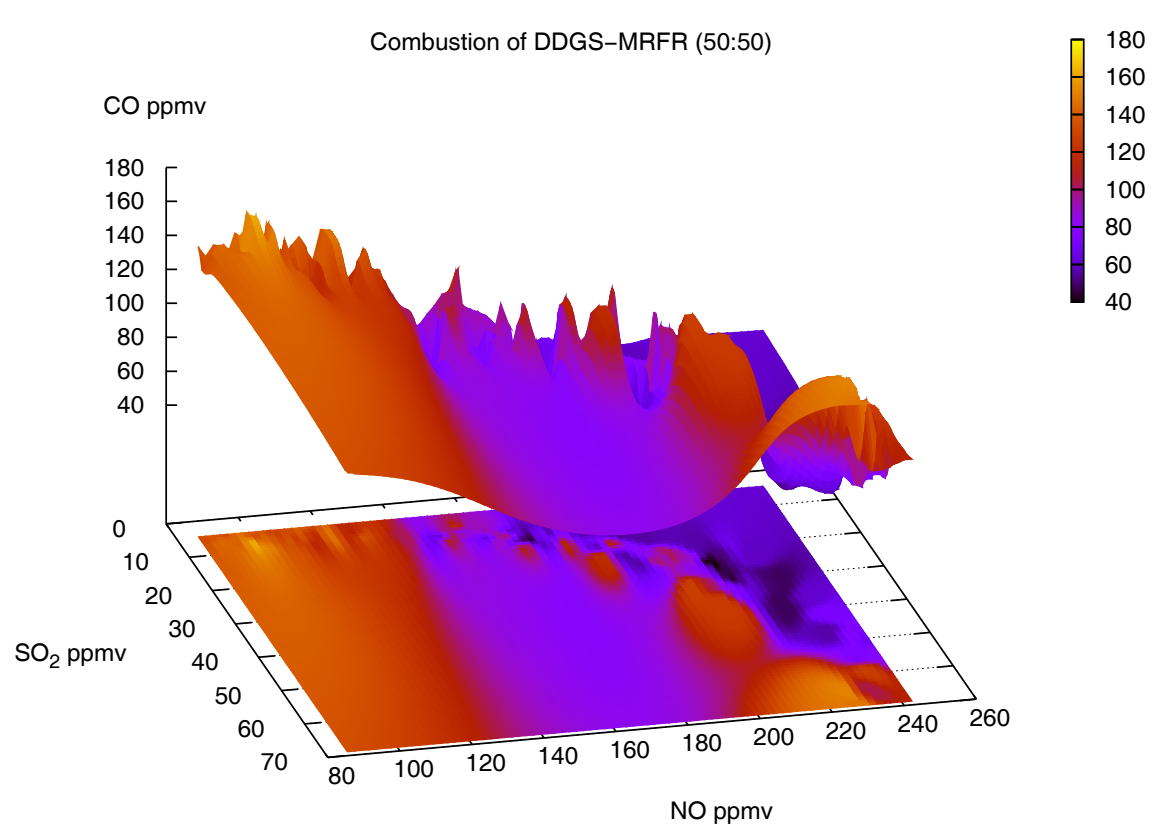

Figure 7 Relationship between simultaneous emissions of $\mathrm{SO}_{2}$, NO and $\mathrm{CO}$; combustion of DDGS-MRFR 50:50. 


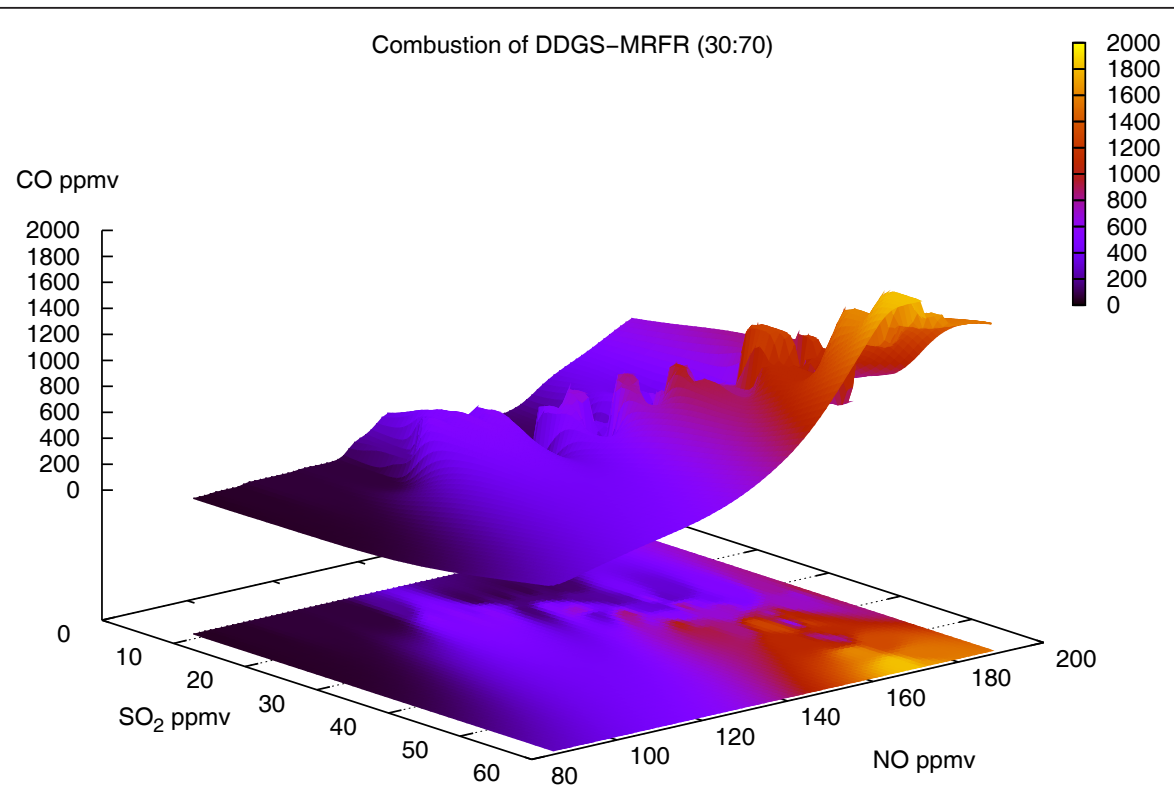

Figure 8 Relationship between simultaneous emissions of $\mathrm{SO}_{2}$, $\mathrm{NO}$ and CO; combustion of DDGS-MRFR 30:70.

component. In addition to sulphur control, the generation of lime (equation 2) has an impact on hydrogen chloride emissions. A secondary reason for the use of limestone in the fluidised bed is the expected removal of hydrogen chloride:

$$
\mathrm{CaO}+2 \mathrm{HCl} \leftrightarrow \mathrm{CaCl}_{2}+\mathrm{H}_{2} \mathrm{O}
$$

This reaction between lime and hydrogen chloride is interesting in consideration of the melting point of calcium chloride $\left(772^{\circ} \mathrm{C}\right)$ which occurs within various areas of the combustor such that calcium chloride deposits should be found within cooler zones of the combustor. For example, during combustion of DDGSMRFR (90:10) the average temperature near the flue gas outlet zone of the fluidised bed combustor was found to be $671^{\circ} \mathrm{C}$ and therefore this suggestion appears plausible. However, competition between chloride and sulphur for reaction with limestone (equations 3,4 and 6 ); reaction kinetics; and thermal stability of the calcium chloride

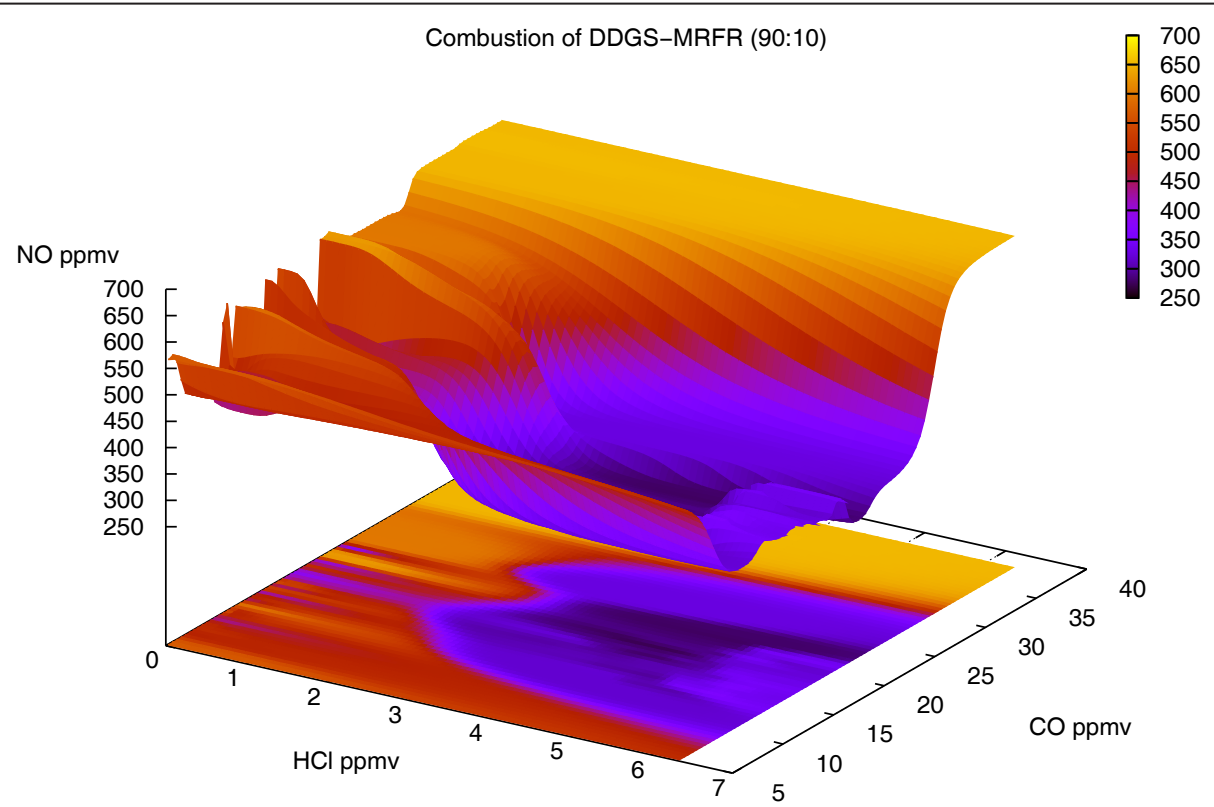

Figure 9 Relationship between simultaneous emissions of $\mathrm{HCl}$, CO and NO; combustion of DDGS-MRFR 90:10. 


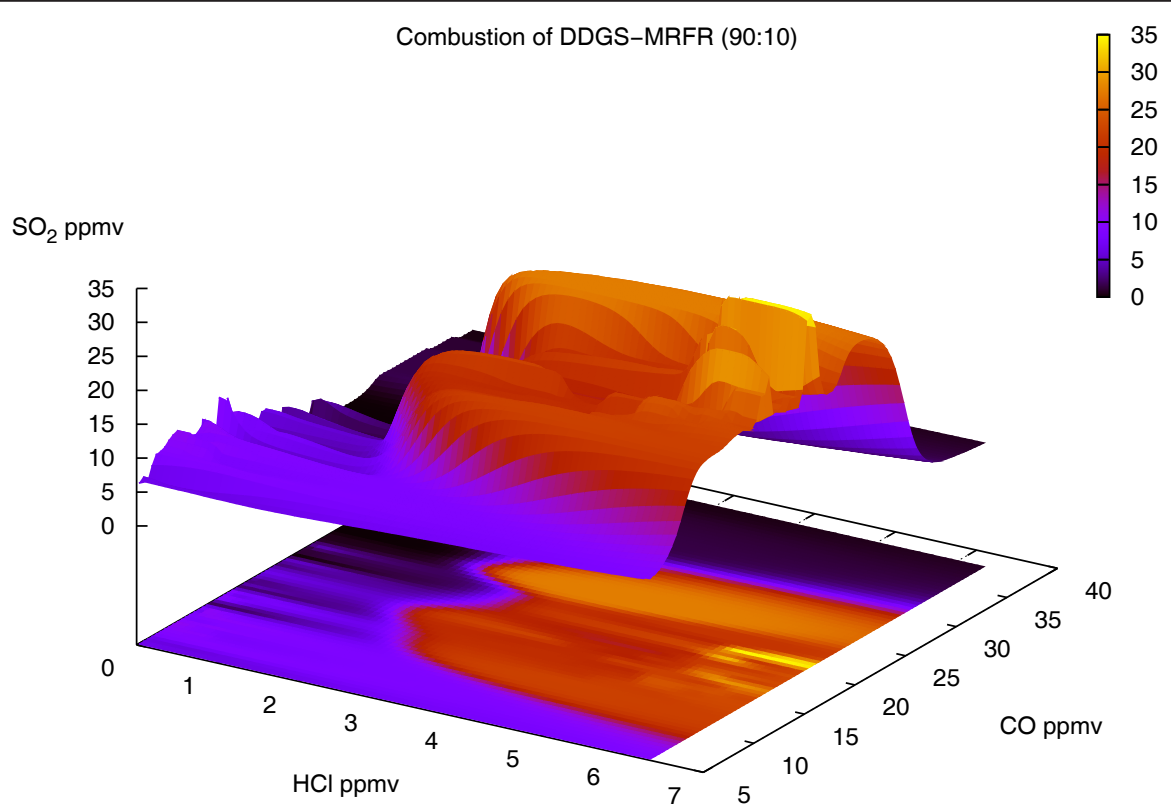

Figure 10 Relationship between simultaneous emissions of $\mathrm{HCl}, \mathrm{CO}$ and $\mathrm{SO}_{2}$; combustion of DDGS-MRFR 90:10.

deposits are additional factors to consider. The consequence of equation 6 is that limestone is not wholly effective in final removal of hydrogen chloride, but instead is involved in reactions causing both generation and consumption of hydrogen chloride. This conclusion is also made elsewhere [12] and would explain the detection of hydrogen chloride as shown in this paper.

Variations in the changes in emissions with the biomass fractions in the fuel mixtures are summarised in Figures 1 and 2. Of surprising interest are emissions of nitric oxide and sulphur dioxide, where the latter is reduced when the waste fraction is added to the biomass. For combustion of biomass fuels using a fluidised bed combustor, the source of nitric oxide emissions is attributed mostly to the nitrogen content in the fuel; this is in contrast to 'thermal' nitric oxides emissions during coal combustion which is performed normally at higher temperatures. Nitrogen content is relatively high in DDGS due to the original protein content; laboratory analysis of the DDGS for these experiments was nearly $5 \%$ by weight (Table 2). This compares to typical nitrogen content for another biomass fuel such wheat, of $1.5 \%$ and is a cause for relatively higher $\mathrm{NO}_{\mathrm{x}}$ emissions with DDGS. In consideration of interactions between nitric oxide and sulphur dioxide as discussed earlier, competition for free radicals between these two pollutants appears to be most evident in the presence of hydrogen chloride and carbon monoxide (Figures 9 and 10). This kinetic competition, especially in the presence of hydrogen chloride would explain why sulphur dioxide emissions are suppressed. Of course, the primary treatment for sulphur dioxide is calcium carbonate, the mechanisms of which are described earlier (equations 1-5).

\section{Conclusions}

Gas analysis of the combustion of biomass with nonrecyclable waste suggests that stable combustion can be achieved and hence gaseous pollutant emissions can be minimised in conjunction with mandatory air pollution control equipment. There was a reduction observed in emissions of nitric oxide and sulphur dioxide when the biomass fraction is substituted for the waste fraction in combustion of the fuel mixtures. A likely explanation for this phenomenon is competition for free radical intermediates to prevent nitric oxide formation, at the expense of sulphur dioxide which itself is then partially converted to calcium sulphate by limestone. The

Table 2 Compositions of DDGS pellets, dimensions 6-8 $\mathrm{mm}$ diameter, $30 \mathrm{~mm}$ length

\begin{tabular}{lcc}
\hline & DDGS & MRFR \\
\hline Carbon & 45.2 & 39.8 \\
Hydrogen & 6.2 & 5.2 \\
Oxygen & 34.1 & 27.2 \\
Nitrogen & 4.91 & 0.9 \\
Chlorine & 0.2 & 0.3 \\
Sulphur & 0.56 & 0.1 \\
Ash & 4.1 & 18.4 \\
Moisture & 4.9 & 8.5 \\
Calorific value (gross, $\mathrm{MJ} \mathrm{kg}^{-1}$ ) & 19.3 & 22 \\
\hline
\end{tabular}


oxidation of carbon monoxide is dependant significantly upon combustion temperature, but this effect may be overcome by the presence (as a catalyst) of hydrogen chloride which reduces the necessary availability of free radical intermediates.

Gas emission data sets from a range of fuel mixes and fluidised bed combustor operating conditions have been generated in this study. It is envisaged that these complex relationships can form the basis for future modelling activities. In summary, fluidised bed concurrent combustion is an appropriate technique to exploit biomass and municipal solid waste resources, without the use of fossil fuels. The addition of municipal solid waste - ideally the non-recyclable fraction as part of a sustainable waste management programme - to biomass combustion has the effect of reducing emissions of some gaseous pollutants.

\section{Experimental}

\section{Fluidised bed combustor design}

The fluidised bed combustor (Figure 11) is based upon the bubbling fluidised bed design, in which hot air of sufficient velocity (in this apparatus, approximately $0.7 \mathrm{~m} \mathrm{~s}^{-1}$ for inlet air at $500^{\circ} \mathrm{C}$ ) is injected into a bed of

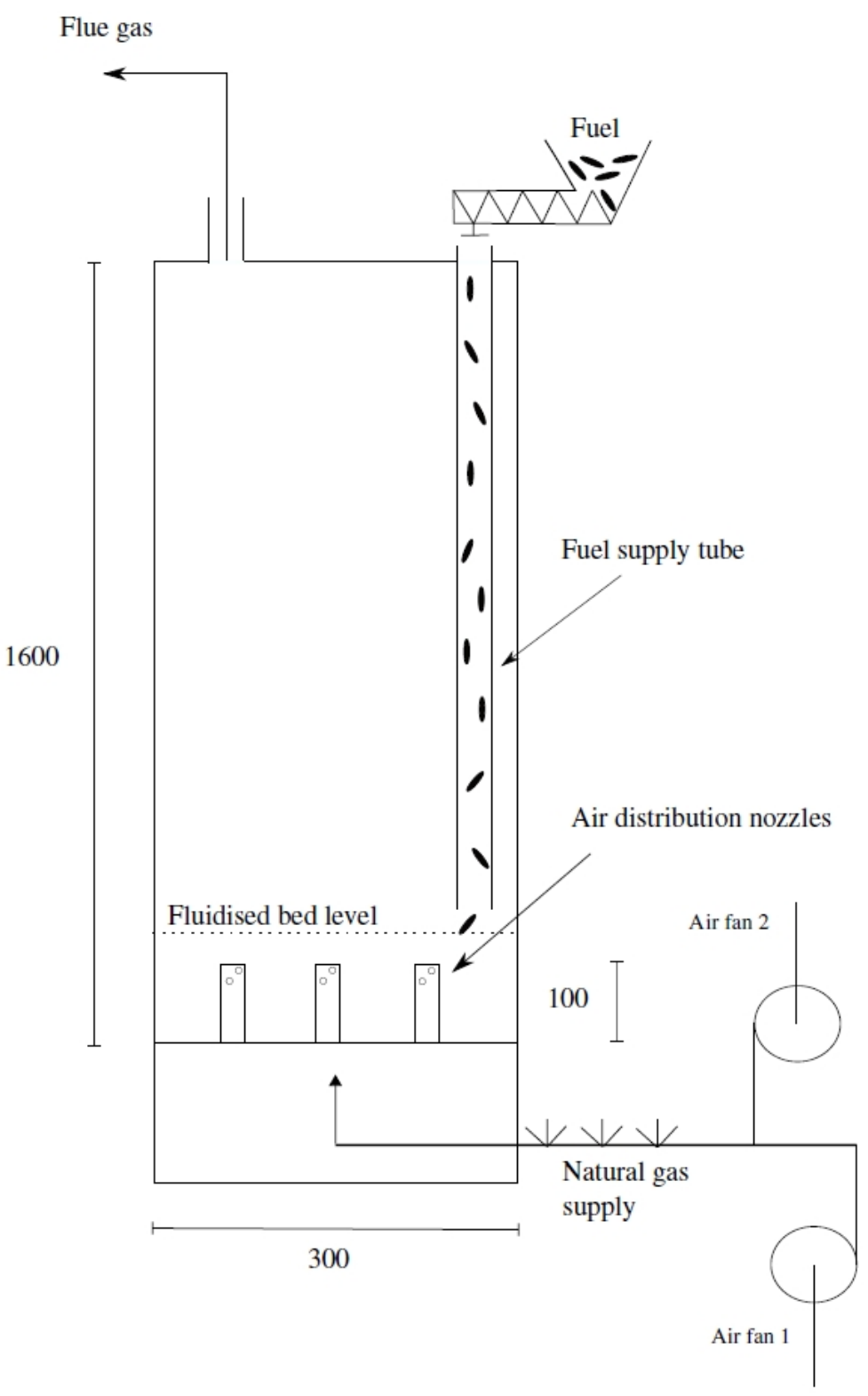

Figure 11 Fluidised bed combustor. Unit of measurement, millimetre. 
inert particles (e.g. sand) to cause the particle to move dynamically in similar way to a viscous liquid. The following diagram shows the features of the combustor used for this experiment. The combustion zone is of cuboid shape, the sides being $300 \mathrm{~mm}$ length, height approximately $1600 \mathrm{~mm}$. The fluidisation air distribution grid comprises nine nozzles, each nozzle having 12 holes. The nozzles are arranged into three linear rows. The fuel feed is of Archimedes screw type, primarily tolerable of pelletised fuels and fuel chips less than $40 \mathrm{~mm}$ particle size. Gas analysis was performed using an FTIR flue gas analyser (Protir 204 M, Protea, Crewe UK), where the flue gas sample was extracted via a sample point maintained at a temperature of $180^{\circ} \mathrm{C}$ and at a location approximately 4-5 metres from the outlet of the combustor.

\section{Fluidised bed material}

Silica sand (97\% quartz, remainder tridymite, crystobalite) of size specification $0.5-1 \mathrm{~mm}$ was used (Garside Sands; Leighton Buzzard, UK). Limestone granules (5 mm particle size, $39.4 \%$ calcium content) were obtained from Tarmac (Buxton, UK).

\section{Fuel characteristics}

The bulk composition of the MRFR fuel fraction selected for this experiment was predominantly $90 \%$ plastics $10 \%$ fibres (paper, cardboard, wood). The material was comminuted to an average particle size of $20 \mathrm{~mm}$ using a laboratory scale cutting mill (Retsch; Haan, Germany). All values shown on 'as received' weight percentages basis.

\footnotetext{
Acknowledgements

The authors wish to acknowledge the Engineering and Physical Sciences Research Council, UK that finances this research through its SUPERGEN-

Bioenergy research consortium.
}

\section{Authors' contributions}

$\mathrm{RL}$ performed all practical experiments and prepared article manuscript; JO and NS made critical review of the manuscript, approved submission of article for publication. All authors read and approved the final manuscript.

\section{Competing interests}

The authors declare that they have no competing interests.

Received: 6 July 2010 Accepted: 1 February 2011

Published: 1 February 2011

\section{References}

1. DEFRA: UK Biomass Strategy. Tech rep Department for Food, Energy and Rural Affairs, London; 2007.

2. DEFRA: Waste Strategy for England 2007. White paper Department of Food and Rural Affairs, London; 2007.

3. Carbon Trust: Biomass sector review for the Carbon Trust. Tech rep Carbon Trust, London; 2005.

4. Hester R, Harrison R, (Eds): Waste Incineration and the Environment. No. 2 in Issues in Environmental Science and Technology Cambridge: Royal Society of Chemistry; 1994
5. Tiffany DG, Morey RV, Kam MD: Transition to a Bioeconomy: Integration of Agricultural and Energy Systems. Use of distillers by-products and corn stover as fuels for ethanol plants Atlanta: Farm Foundation; 2008.

6. Boavida D, Abelha P, Gulyurtlu I, Cabrita I: Co-combustion of coal and non-recyclable paper and plastic waste in a fluidised bed reactor. Fuel 2003, 82(15-17):1931-1938.

7. van Loo S, Koppejan J, (Eds): The handbook of biomass combustion and cofiring London: Earthscan; 2008.

8. Wei $X$, Schnell U, Han $\mathrm{X}$, Hein KRG: Interactions of $\mathrm{CO}, \mathrm{HCl}$, and $\mathrm{SO}_{\mathbf{x}}$ in pulverised coal flames. Fuel 2004, 83(9):1227-1233.

9. Gokulakrishnan P, Lawrence A: An experimental study of the inhibiting effect of chlorine in a fluidized bed combustor. Combustion and Flame 1999, 116(4):640-652.

10. Julien S, Brereton CMH, Lim CJ, Grace JR, Anthony EJ: The effect of halides on emissions from circulating fluidized bed combustion of fossil fuels. Fuel 1996, 75(14):1655-1663.

11. Glassman I, Yetter RA: Combustion. Fourth edition. London: Academic Press Inc. (London) Ltd; 2008.

12. Lawrence $A D, B u J$ : The reactions between $\mathrm{Ca}$-based solids and gases representative of those found in a fluidized-bed incinerator. Chemical Engineering Science 2000, 55(24):6129-6137.

doi:10.1186/1752-153X-5-4

Cite this article as: Laryea-Goldsmith et al:: Gaseous emissions during concurrent combustion of biomass and non-recyclable municipal solid waste. Chemistry Central Journal 2011 5:4.

\section{Publish with ChemistryCentral and every scientist can read your work free of charge \\ "Open access provides opportunities to our colleagues in other parts of the globe, by allowing anyone to view the content free of charge." W. Jeffery Hurst, The Hershey Company.}

- available free of charge to the entire scientific community

- peer reviewed and published immediately upon acceptance

- cited in PubMed and archived on PubMed Central

- yours - you keep the copyright

Submit your manuscript here:

http://www.chemistrycentral.com/manuscript/<smiles>c1ccccc1</smiles>

ChemistryCentral 